\title{
Level of Real Wages and Labour Productivity in the Manufacturing Sector of the Punjab
}

\author{
NAHEED ASLAM*
}

The study analyses the determination of the level of real wages and labour productivity across industries as well as over time in a simultaneous-equation framework. It has been postulated that an increase in real wages leads to a greater intensity of effort on the part of workers, resulting in higher productivity within a certain range. Higher productivity denotes an improvement in the "ability to pay" and results in payment of higher wages. The study finds that real wages and productivity are significantly related with each other.

\section{INTRODUCTION}

The level of real wages represents income to workers, costs to businessmen and a major source of purchasing power to wage earners. As such, it has significant implications for such economic variables as productivity, investment, employment, price stability and level of welfare. This paper focuses on inter-industry wage differentials and the determination of wage level over time.

Economic literature abounds in empirical studies which attempt to identify the determinants of real wages over time as well as across industries. Nevertheless, keeping in view the underdeveloped and labour-abundant character of Pakistan's economy, we shall refer here only to those studies which have been carried out for underdeveloped countries. Guisinger and Irfan [6] blamed government intervention, trade unions and employers for wage increases. However, they did not provide empirical evidence as to the relative importance of these three factors. In another study, using data on Pakistan's large-scale manufacturing for 1949-69, Irfan [11]

*The author is a Staff Economist at the Pakistan Institute of Development Economics, Islamabad. She is deeply indebted to Professor Syed Nawab Haider Naqvi for his invaluable advice, constructive discussions and constant encouragement. She also wishes to express her appreciation to anonymous referees of the Review for their helpful criticism. The author also wishes to thank Mr. Syed Hamid Hasan Naqavi for his excellent editorial help and Mr. Mohammad Rafiq for computer assistance. Thanks are also due to Mr. Ghulam Raza for his help with typing several drafts of this paper. The author alone is responsible for any remaining errors and omissions. 
estimated a set of three simultaneous equations in which real-wage changes and growth in unionization and industrial employment were assumed to be jointly determined. As far as analysis of inter-industry wage differentials is concerned, two more studies, one by Guisinger and Irfan [5] and the other by Irfan [10], were carried out for Pakistan.

The present study is however different from the studies mentioned above in that, in addition to some of the variables included in those studies, it includes labour productivity also as an argument in the wage equations.

Horowitz [9] also conducted a study on wage determination in India in both cross-sectional and time-series frameworks. She argued that wage increases in India did not result from government policy or trade union's efforts: instead, it was economic considerations that played the most significant role, viz. employers pay higher wages because, within certain range, higher wages result in higher productivity. However, she did not test the impact of higher wages on labour productivity.

The present study, however, tries to quantify the effect of higher wages on productivity and attempts to provide empirical evidence on simultaneous determination of inter-industry differentials in wages and labour productivity across 'twentyfour' different industries for the year $1977-78$ as well as on determination of wages and labour productivity over time in the manufacturing sector of the Punjab for the 1964-65-1977-78 period.

The plan of the paper is as follows. The first section discusses the model, methodology and data. The second section deals with empirical results, while the third section summarizes the major conclusions and policy implications, and points out the limitations of the present study.

\section{MODEL, METHODOLOGY AND DATA}

In this paper, inter-industry wage differentials as well as wage determination over time have been analysed within the framework of two simultaneous equations. The endogenous variables of the model are wages and labour productivity, while there are seven exogenous variables in the system.

In the cross-sectional analysis, a two-equation model is specified as follows:

W

$=f(L P, K / L, C R, E O, P, T R)$;

$L P$

$=f(W, K / L, O, P$ vs $P)$;

where

$L P \quad=\quad$ The value added divided by the number of persons employed;

$K / L=$ Capital intensity (value of fixed assets divided by the number of persons employed);
$C R=$ Four-firm concentration ratio;

EO = Export orientation ( $=$ the value of exports as a fraction of the output of an industry);

$P \quad=\quad$ A proxy for profitability calculated as the non-wage value added, divided by the value of output;

$T R=$ Weighted average tariff rate;

$W \quad=\quad$ Average earnings per employee, including fringe benefits;

$O \quad=$ Output level; and

$P$ vs $P=$ Public-versus-private-sector dummy variable which takes the value of unity for public-sector industries and of zero otherwise.

Developing and expanding industries may need steadily increasing skills to a greater extent than other industries, and, because of their rising productivity, may be in a position to pay higher wages. As such, inter-industry wage differentials are largely a reflection of differences in the skill compositions of labour and the capacity-to-pay of different industrial units. However, owing to non-availability of data on skill index, we have not been able to test the impact of that index on wages. This is an acknowledged shortcoming of the analysis.

In the time-series analysis, the two-equation model is specified as follows :

$$
\begin{array}{ll}
W & =f\left(L P, G D P_{P}, D E, E D\right) \\
L P & =f(O, K / L, W, D E)^{1}
\end{array}
$$

where

$W \quad=\quad$ Average yearly earning of workers deflated by the consumer price index for industrial workers;

$G D P_{P}=$ Gross domestic product at constant factor cost divided by tota population;

$K / L=$ Capital intensity, i.e. capital stock deflated by investment price index and divided by the number of the persons employed;

$O=$ Output in the manufacturing sector at constant prices;

${ }^{1}$ It should be noted that the labour-productivity equation has not been derived from a production function and, as such, the coefficient of wages does not represent the elasticity of substitution between labour and capital. 
$=$ Dummy variable for emigration, which assumes the value of unity for the period 1971-72 to 1977-78 and of zero otherwise; and

$=$ An interactive variable of employment and dummy variable for emigration $=$ DEXE

The major emphasis of our study is on testing the relationship between wages and labour productivity. There are two aspects of this relationship which we test with the help of the census of large-scale manufacturing data in both the crosssection and time-series analyses, viz. (a) higher labour productivity results in higher wages, and (b) higher wages result in higher labour productivity within a certain range.

First we discuss the relevance of labour productivity for wage equations.

The source of improvement in real wages is an increase in productivity. In any economy, productivity increases may be utilised for raising wages, distributing dividends and profits, and reducing prices. The scope of the present analysis is confined to examining the impact of higher productivity on real wages.

Increases in productivity can arise from different sources; e.g. through greater efforts of labour and through greater mechanisation, improved technology and better managerial skills. To the extent that higher labour productivity is the contribution of labour either through greater intensity of effort or because of better skill content of the labour force, productivity increases justify proportional wage increases. However, if higher labour productivity is due to improvement in other factors, then proportional wage increases would introduce unjustifiable inequalities in the wage structure and, as a result, the wage structure would have little relationship with skill and quality of labour. The gains of productivity should be shared by all and the best way to share these gains is through reduced prices. However, reducing wages in high-productivity industrial units is extremely difficult. Moreover, there are economic considerations behind the payment of high wages by these units. D.G. Brown [2], the major proponent of the "ability to pay" hypothesis, argued that liberal wage policies increase workers' goodwill, simplify recruitment and reduce costly turnover. On the other hand, low wages induce labour turnover and even for the least skilled jobs, substantial cost is involved in hiring and training new workers. As such, employers will have a better bargain if they can induce workers to stay on with better wages. $^{2}$ In this way, they would more than recoup the investment expenditure on workers' training and would avoid additional outlays. Therefore, higher productivity, which is used as a proxy for the "ability to pay", is expected to induce higher wages.

${ }^{2}$ Bhagwati and Ramaswami [1] argued that employers pay better wages on account of "prestige cum humanitarian grounds". This may be one of the factors behind payment of higher wages. On logical grounds, however, economic considerations seem to be more relevant.
We now discuss the second aspect of the relationship between wages and labour productivity, viz. within a certain range, higher real wages result in higher labour productivity.

In the literature on economic development, this theory has been put forward in different forms by $\mathrm{H}$. Leibenstein [16] and by Fei and Chiang [3]. Leibenstein distinguished between supply of labour-time (man-hours or man-years) and the supply of work (or effort). According to him, "the average productivity of a group of men will depend on their wage. Up to some point, the higher the wage, the higher the per capita productivity for the group, because the higher the wage, the greater the units of work per man" $[16$, p. 67].

By postulating a Cobb-Douglas type of production function, Fei and Chiang [3] derived an effort function of the following form:

$$
\phi=\phi(W)
$$

where $W$ is the real wage and $\phi$ is the coefficient of productive effort. On the assumption that a typical worker is not able to save, the consumption standard is identified with the real wage. The model treats consumption not as an end in itself but as an indirect input whose ultimate effect is felt through its effect on the efficiency of labour. Hence, the higher the real wages, the higher the level of productivity up to some point.

An S-shaped ${ }^{3}$ effort function is postulated to represent a typical worker's supply curve of efficiency as a function of real wage.

${ }^{3}$ When consumption level is below a certain minimum level, $R$ the coefficient of productive effort, $\phi$, will be nil. reason, $\Omega 1$ is called starvation region. $\Omega 2$ is called deficiency region, since the consumption standard at $R$ is exceedingly low; successive equal increments in $W$ will tend to result in increasing incremen deficiency region. In increments in $\phi$ in the consumption stand In the sufficiency region, consumption standard is sufficiently high to set in motion the operation of a "law of diminishing marginal productive effort" point $T, E \phi=1$. After $T, E \phi<1$. Since there exists an absolute upper bound in productive effort of a typical worker, the effort curve tends to approach a horizontal asymptote for high values of real wages in region
$\Omega 4$.

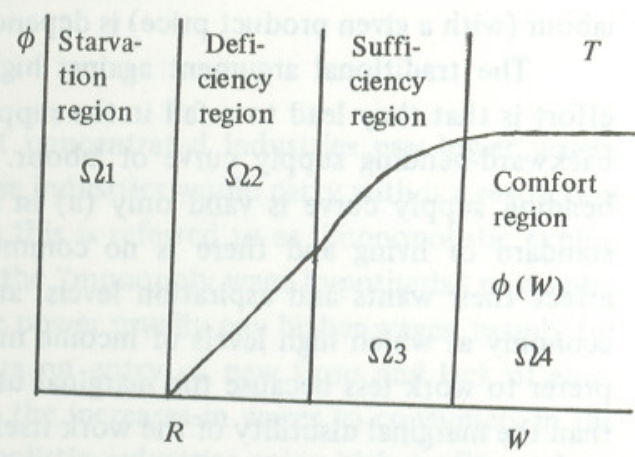

A similar type of functional relation been applied by Leibenstein [16] to the study of the problem of disguised unemployment.
However, unlike Fei and Chiang [3] ments may at first lead to increasing increments in the possibility that successive wage-rate incre- 
These economists confine their analysis to the effect of wages on productivity through better health and nutrition. Following Horowitz [9], we assume that higher wages capture the effect of better incentives and labour stability in addition to that of better health and nutrition.

According to Horowitz, wage productivity nexus has its positive and negative aspects. In its negative aspect, higher wages provide insurance against slow-downs and sabotage and in its positive aspect they contribute to better health and hence greater effort. Also, higher wages help motivate performance at higher levels of efficiency because the worker feels that he or she is being paid more equitably for the effort put forth $[9$, p.670]. Furthermore, a part of the increase in wages is ascribable to improvement in the quality of labour or to labour-embodied technological improvement, which also leads to higher productivity.

Following Fei and Chiang [3], we also assume diminishing returns on marginal units of investment in labour after a point, implying that after a point $E \phi$, i.e. $\left(\frac{d \phi}{d w} \cdot \frac{w}{\phi}\right)$ will be less than unity.

At this juncture, it will be interesting to see how the present theory compares with the traditional economic theory. Under the traditional theory, all units of labour have the same intensity of effort. Once it is assumed that labour varies in terms of its intensity of effort because it is not used to its full capacity, then it can be hypothesized that higher wages lead to greater effort on the part of workers. The equality of marginal cost with marginal revenue still remains the condition for profit maximisation. However, the marginal revenue accruing from an additional unit of labour (with a given product price) is dependent on the marginal cost incurred on it.

The traditional argument against higher wages as an inducement for greater effort is that they lead to a fall in the supply of labour, graphically represented by a backward-bending supply curve of labour. However, the hypothesis of backwardbending supply curve is valid only (a) in an economy where people have a fixed standard of living and there is no communication with the rest of the world to affect their wants and aspiration levels, and (b) at a highly advanced stage of an economy at which high levels of income may lead to a situation where people may prefer to work less because the marginal utility of earnings from work may be lower than the marginal disutility of the work itself.

Neither of these two conditions obtains in Pakistan. Therefore, we may well expect the impact of higher wages on amount of work to be positive within a certain range.

The implication of the two-sided relationship between wages and labour productivity discussed above is that the direction of causation between these two variables can not be established conclusively, nor will it be reasonable to assume that the relationship is entirely unidirectional. Therefore, in our analysis wages and labour productivity are assumed to be jointly determined. It may be noted that labour productivity is not a predetermined but a random variable and, as such, if OLS is applied its effect on wages would be systematically overestimated or underestimated depending on whether the value of the disturbances is positive or negative. The application of the OLS will yield positive inconsistency in estimates in the first case but a negative inconsistency in estimates in the second case. Therefore, we have estimated these variables simultaneously, with the help of the Two-Stage LeastSquares (2SLS) technique. The idea behind the 2SLS is to purge the explanatory variable of the stochastic component associated with the random term. This is achieved by regressing the endogenous variables on all the exogenous variables in the system and then replacing these variables by their estimated values.

The theoretical rationale for the inclusion of the rest of the independent variables in wage equations is given below.

\section{Cross-Sectional Wage Equation}

\section{Profitability}

In addition to labour productivity, the profitability of industry will also be used as an indicator of the ability to pay. Higher productivity and profitability provide permissive conditions for higher wages. Direct data on industry's profitability are not available and therefore non-wage component of the value added, deflated by the value of output, is used as a proxy for profit rates. This variable admittedly includes, in addition to profits, depreciation charges, property taxes, insurance, etc.

\section{Concentration Ratio}

Simple theory might suggest that concentrated industries pay lower wages, since output restriction practised by these industries would carry with it a restriction of employment. In economic literature this is referred to as "monopolistic exploitation hypothesis". On the other hand, the "monopoly wage hypothesis" postulates that industries which enjoy monopolistic power usually pay higher wages, mainly for two reasons. Firstly, because of barriers on entry of new firms and lack of competition, it is easier for them to pass on the increases in wages to consumers in the form of higher prices. Secondly, monopolistic industries enjoy high profits, and are thus able to pay higher wages. Our study attempts to investigate whether concentrated industries in Pakistan pay higher wages or lower wages.

\section{Capital Intensity}

Specific types of skills are required to operate different types of machines. Therefore, a high degree of capital intensity usually implies inelastic demand for labour. Moreover, the high fixed costs created by high capital-intensity make labour turnover and carelessness on the part of the workers even more expensive to the 
employers. Therefore, capital-intensive industries are expected to pay higher wages in order to minimize the risk of labour turnover. Capital intensity also implies quasi-rent, partly because capital assets tend to be long-lived. Quasi-rent also arises from the monopolistic nature of capital-intensive industries, which is a result of tariff protection, licences and other such privileges granted to those industries. This partial-monopoly position may also create opportunities for labour to exact monopoly rents.

\section{Export Orientation}

Export-oriented industries are expected to pay lower wages because higher wages, due to higher demand elasticity of exportables, may lower profits rather than increase prices in those industries. Moreover, the existence of low wages in exportoriented industries may also be explained by the skill composition of the labour used in those industries. Anne O. Krueger [14] found that in developing countries, exportoriented industries tend to employ a greater proportion of unskilled labour than of skilled labour. As a result, they are expected to pay lower wages.

\section{Tariff Protection}

Our paper also attempts to determine the effect of protection ${ }^{4}$ granted by imposition of tariffs on wages.

\section{Time-Series Wage Equation}

Given below are the rest of the variables used in this study which are regarded as determinants of wages over time.

\section{Gross Domestic Product Per Capita}

To determine if the manufacturing wages have grown faster or slower than the incomes of all other groups - capitalists, landlords, employees in the government sector, etc. - real wages are regressed against per capita GDP at constant factor cost. The elasticity of wages with respect to per capita GDP can be offered as a crude indicator of a country following a high-wage or low-wage policy. Moreover, per capita GDP can also be regarded as an indicator of a country's capacity to pay, and, as such, is expected to affect-wage level.

${ }^{4}$ Lewis [17] and Hagen [7] argued that domestic distortion caused by the alleged divergence between the social marginal rate of transforming agriculture into manufacturing and the market price ratio should be corrected by providing protection to the manufacturing sector. However, Naqvi [19] has shown that this argument is fallacious and recommended a more direct approach to deal with this situation, that is to reduce the rural money wage or to subsidise the wages in the manufacturing sector.

\section{Dummy Variable for Emigration}

Emigration of labour force affects wages indirectly through affecting the elasticity of the labour-supply curve. The elasticity of labour supply is expected to be lower when emigration is possible than when there is no migration. A dummy be lower when emigration is palue of unity for the years when labour force migrated to the Middle Eastern countries and of zero otherwise, is used to test the effect of migration on wages.

\section{Interactive Variable of Employment and} Dummy Variable for Emigration

Furthermore, an interactive variable of employment and a dummy variable for emigration is introduced in the specification to see the combined effect of these two variables on wages, while the dummy variable for emigration represents the availability of alternative job opportunities in the present context. Employment opportunities elsewhere affect the voluntary mobility of labour. When jobs are plentiful, workers will quit far more readily than when jobs are scarce. In view of the existence of high-paying jobs in the Middle Eastern countries, the employers may be compelled to pay even higher wages in order to retain the workers already employed.

\section{Labour Productivity Equation}

The variables discussed below are the ones that are expected to determine inter-industry productivity differentials.

\section{Output Level}

The output level which reflects economies of scale is expected to exert a positive influence on labour productivity. As the scale of output increases, labour economies are achieved through specialisation and division of labour. Moreover, large-scale operations provide considerable experience to technical personnel leading to improvement in labour skills and, in turn, to higher labour productivity.

\section{Capital Intensity}

Capital intensity is one of the very important factors affecting labour productivity. An appropriate variable which can better explain changes in labour productivity is capital stock adjusted for changing rates of utilization. However, data are not available on capacity utilization and, therefore, unadjusted capital stock has been used. 


\section{Public-versus-Private-Sector Dummy Variable}

A Public-versus-private-sector dummy variable is also included in the labourproductivity equation to see if labour productivity is higher in the public-sector industries or in the private-sector industries.

In the time-series analysis, in addition to output level, capital intensity and wages, which are believed to determine productivity growth over time, a dummy variable for emigration has also been introduced in the labour-productivity equation to test the generally held notion that migration of labour has caused productivity to fall in the industrial sector.

The primary source of data for the study is the Census of Manufacturing Industries (CMI) [23]. The data on wages, output, employment and value of fixed assets have been taken from the $C M I$. Data on value of exports have been taken from the Foreign Trade Statistics of Pakistan [21], whereas data on consumer price index have been taken from different issues of the monthly Statistical Bulletin [20] and those on manufacturing price index from the Pakistan Economic Survey [22]. Concentration ratios have been obtained from [13], while tariff rates have been taken from $[8]$.

\section{EMPIRICAL RESULTS}

This section is divided into two parts; in the first part results pertaining to inter-industry differentials in wages and labour productivity, as presented in Table 1, have been discussed, while the second part discusses the results relating to determination of wages and labour productivity over time.

\section{Wage Equation}

Wage Equations 1 and 2 in Table 1 show that labour productivity is significant at the 5-percent level of significance, indicating that industrial units' differential ability to pay is an important determinant of inter-industry wage differentials.

Capital intensity is significant at the 5-percent level of significance (Wage Equation 3), indicating that more capital-intensive industries pay wage premium to reduce labour turnover.

The negative sign of export orientation is in accord with a priori expectations that export-oriented industries, being major employers of unskilled labour,would pay lower wages than other industries. However, this variable is insignificant at conventional levels.

There is no evidence to suggest that concentrated industries pay lower wages. On the contrary, our results show that concentrated industries pay higher wages. However, this positive relationship may be due to the fact that these industries get better-quality workers. To the extent workers are of better quality, high wage rates are offset. Moreover, non-economic factors like threat of unionism may also induce

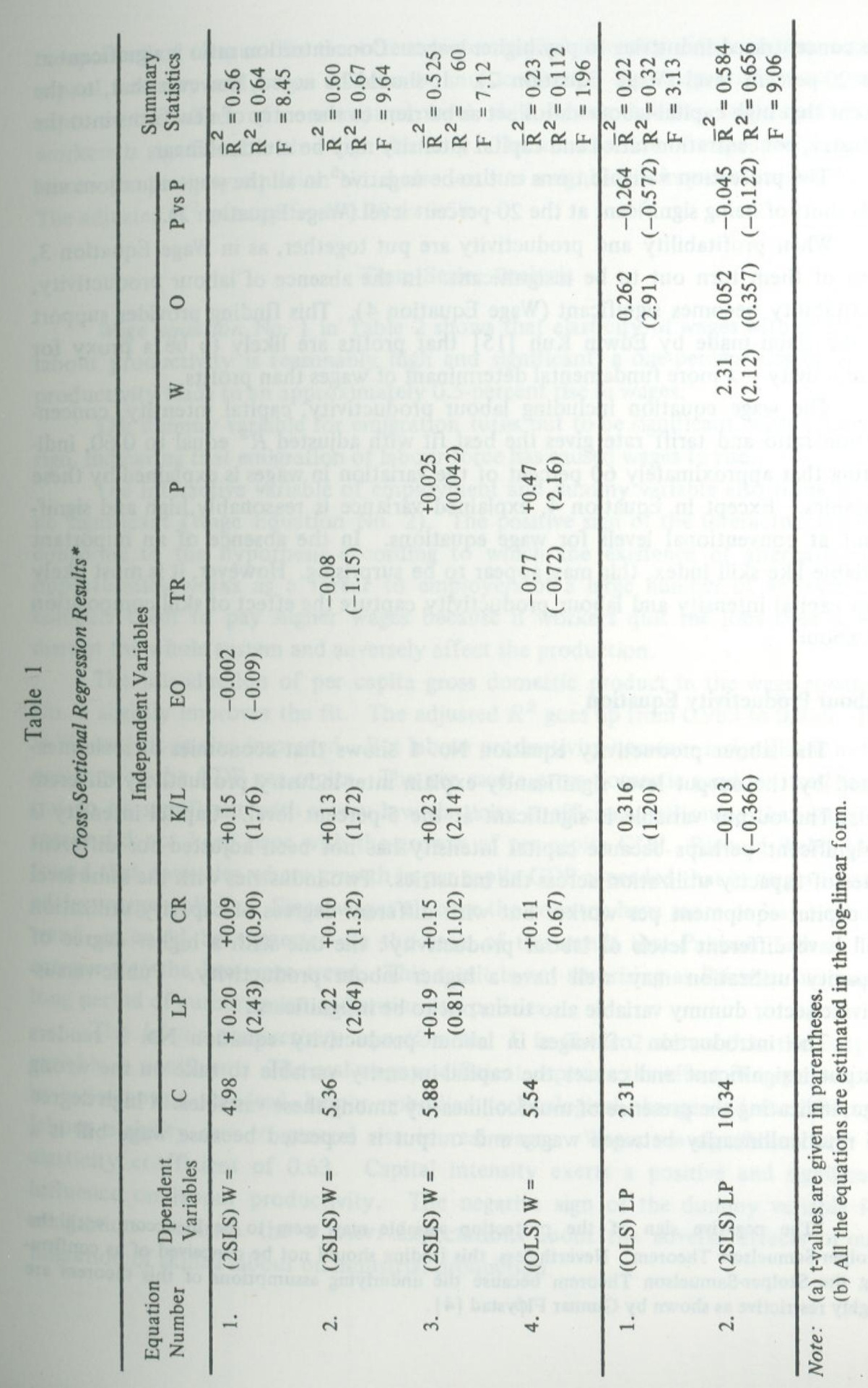


the concentrated industries to pay higher wages. Concentration ratio is significant at the 20-percent level (Wage Equation 2). It should be noted, however that, to the extent that high capital-labour ratios act as barriers to the entry of new firms into the industry, concentration ratios and capital intensity may be multicollinear.

The protection variable turns out to be negative $e^{5}$ in all the wage equations and falls short of being significant at the 20-percent level (Wage Equation 2).

When profitability and productivity are put together, as in Wage Equation 3, both of them turn out to be insignificant. In the absence of labour productivity, profitability becomes significant (Wage Equation 4). This finding provides support to the claim made by Edwin Kuh [15] that profits are likely to be a proxy for productivity - a more fundamental determinant of wages than profits.

The wage equation including labour productivity, capital intensity, concentration ratio and tariff rate gives the best fit with adjusted $R^{2}$ equal to 0.60 , indicating that approximately 60 percent of the variation in wages is explained by these variables. Except in Equation 4, explained variance is reasonably high and significant at conventional levels for wage equations. In the absence of an important variable like skill index, this may appear to be surprising. However, it is most likely that capital intensity and labour productivity capture the effect of skill composition of labour.

\section{Labour Productivity Equation}

The labour productivity equation No. 1 shows that economies of scale measured by the output level significantly explain inter-industry productivity differentials. The output variable is significant at the 5-percent level. Capital intensity is insignificant perhaps because capital intensity has not been adjusted for different rates of capacity utilization across the industries. Two industries with the same level of capital equipment per worker but with different degrees of capacity utilization will have different levels of labour productivity: the one with a higher degree of capacity utilization may well have a higher labour productivity. Public-versusprivate-sector dummy variable also turns out to be insignificant.

The introduction of wages in labour productivity equation No. 1 renders output insignificant and causes the capital-intensity variable to take on the wrong sign, indicating the presence of multicollinearity among these variables. A high degree of multicollinearity between wages and output is expected because wage bill is a

${ }^{5}$ The negative sign of the protection variable may seem to be in accord with the Stolper-Samuelson Theorem. Nevertheless, this finding should not be conceived of as confirming the Stolper-Samuelson Theorem because the underlying assumptions of this theorem are highly restrictive as shown by Gunnar Flфystad [4]. component of output. To the extent higher capital intensity induces higher wages, capital intensity and wages will also be multicollinear. The wage coefficient which captures the effect of consumption level, skill, labour stability and incentives to workers is significant with a high elasticity. The introduction of wage variable in the labour productivity equation No. 1 also leads to a significant improvement in the fit. The adjusted $R^{2}$ goes up from 0.22 to 0.58 .

\section{Time-Series Analysis}

Wage equation No. 1 in Table 2 shows that elasticity of wages with respect to labour productivity is reasonably high and significant; a one-percent rise in labour productivity leads to an approximately 0.5 -percent rise in wages.

The dummy variable for emigration turns out to be significant, with a positive sign, indicating that emigration of labour force has caused wages to rise.

The interactive variable of employment and dummy variable also turns out to be significant (Wage Equation No. 2). The positive sign of the interactive variable conforms to the hypothesis according to which the existence of alternative job opportunities works as a threat to employers of a large number of workers and compels them to pay higher wages because if workers quit the jobs then it will disrupt the whole system and adversely affect the production.

The introduction of per capita gross domestic product in the wage equation No. 1 slightly improves the fit. The adjusted $R^{2}$ goes up from 0.983 to 0.986 . The D.W. statistic is also improved. But labour productivity becomes insignificant in the presence of the GDP per capita. The per capita gross domestic product itself turns out to be significant with a very low elasticity coefficient, indicating that wage increase did not keep pace with the growth of per capita GDP. Richard Webb [24] found that countries where growth in per capita GDP exceeded that in wages followed low-wage policies. Since wages all over the country have more or less a similar trend, it could be suggested on the basis of this result that Pakistan falls in the category of the low-wage trend. This result is not surprising as Pakistan has had a long period of authoritarian and anti-union policies.

The labour productivity equation No. 1 in Table 2 shows that the output variable is significant. The real-wage coefficient captures the effect of improvement in consumption standard, labour-embodied technological change and the effect of labour stability due to general rise in real wages. Wages are significant with an elasticity coefficient of 0.63 . Capital intensity exerts a positive and significant influence on labour productivity. The negative sign of the dummy variable for emigration confirms the a priori expectations about the adverse effects of outmigration of skilled labour on industrial production. 


\section{CONCLUSION AND POLICY IMPLICATIONS}

The general conclusion that emerges from our results is that wages and labour pretivity are :mportant determinants of each other. Correlation between wages and productivity for aggregate of industries from 1964-65 to 1977-78 is high Similarly, correlation between wages and productivity among industries is high. On both counts, the evidence suggests that productivity-induced wage rise is significant, implying that the capacity-to-pay criterion has to some extent characterised the manufacturing sector, and the capacity-to-pay criterion is motivated by political convenience and by notions of fairness. These factors do not hold very bright prospects for more equitable and employment-creating wage policies. Moreover, the capacity-to-pay criterion tends to sanction and reinforce the dualism and income differentials between modern and traditional sectors.

The evidence based on both cross-sectional and time-series analyses also shows that the effect of wages on productivity is significant, which is reflective of the fact that higher wages lead to higher labour productivity within a certain range. Productivity can rise in two distinct ways: firstly, through more intensive effort on the part of the workers and, secondly, through greater mechanisation, improved technology and better management. The higher wages, for the most part, reflect the impact of former factor on productivity. Wages can be referred to as one of the extrinsic rewards which are meant to satisfy the "lowest-level needs". 6 As the average Pakistani worker exists at a subsistence level, financial considerations, which satisfy the lowest-level needs, may be very important for him. However, the positive impact of wages on labour productivity should not lead one to make it an argument for raising wages further in those industries in which they are already artificially high and prevent employment generation.

The positive impact of the interactive term on wages (of employment and dummy variable for emigration) lends support to the view that in the present avail ability of high-paying jobs in Middle-Eastern countries which provide an opportunity to the workers to avail themselves of these jobs, the increase in employment has led to a rise in real wage level which can render the jobs in the manufacturing secto more attractive and minimise labour turnover. Furthermore, the negative impact of the dummy variable for emigration on labour productivity indicates that emigration of labour force has been costly to the economy in terms of production losses. These results show that outmigration has caused wages to rise, and this can adversely affect the comparative advantage of the country, as rising wages can deter export expansion by raising the costs of production of Pakistan's exports. Moreover, the simultaneous

${ }^{6}$ See [18]. According to Maslow, the hierarchy of needs in the ascending order of importance is as follows: (i) physiological and security needs; (ii) social esteem needs; and (iii) selfactualization needs. 
inflow of remittances and the fall in industrial production due to outmigration of skilled labour adds to inflationary pressures in the economy.

The study also found that real wages have significantly lagged behind per capita GDP, indicating that wage restraint has been practised. Since wage restraint in Pakistan has been paralleled by low pricing of capital, licensing and other such policies as subsidised capital, particularly in the manufacturing sector, it is most likely that these factors have offset any employment creation that could have resulted from low wages.

\section{Limitations of the Analysis}

The main problem confronted in the analysis is the non-availability of data on some of the very important variables like skill index and capacity utilization. As is well known, an increase in wages over time is a result of improvement in labour skills. Furthermore, inter-industry wage differentials reflect to a large extent differences in skill composition of labour. Improvement of skills is also believed to be the main cause of high labour-productivity. However, the impact of skill index on these variables could not be tested owing to non-availability of the relevant data.

Capital intensity, unadjusted for rate of utilization, is not a very useful determinant of labour productivity, since two plants with equal capital stock but with different capacity utilization will have different effective capital-labour ratios. With an increase in the capacity utilization rate, labour productivity will grow despite the absence of any capital-deepening. However, data on capacity utilization are not available. Therefore, unadjusted capital stock has been used in this study.

\section{REFERENCES}

1. Bhagwati, J., and V.K. Ramaswami. "Domestic Distorations, Tariffs and the Theory of Optimum Subsidy". Journal of Political Economy. February 1963.

2. Brown, G. David. "Expected Ability to Pay and Inter-Industry Wage Structure in Manufacturing”. Industrial Labour Relations Review. Oct. 1962.

3. Fei, C.H. John, and Alpha C. Chiang. "Maximum Speed Development through Austerity". In Irma Adelman and Erik Thorbecke (eds.), The Theory and Design of Economic Development. Baltimore: The Johns Hopkins University Press. 1966.

4. Flфystad, Gunnar. "Real Wages, Factor Prices \& Gains from International Trade". International Economic Review. February 1972.

5. Guisinger Stephen, and M. Irfan, "Inter-Industry Differentials in Wages and Earnings in Pakistan's Manufacturing Sector". Pakistan Development Review. Autumn 1975
6. Guisinger, Stephen, and M. Irfan, "Real Wages of Industrial Workers in Pakistan : 1954 to 1970". Pakistan Development Review. Winter 1974.

7. Hagen, Everette. "An Economic Justification for Protection". The Quarterly Journal of Economics. Nov. 1958.

8. Hamid, Shahnaz. "Structure of Tariff in Pakistan During 1960-61 - 1979-80". (Unpublished: available from the author at the Pakistan Institute of Development Economics, Islamabad)

9. Horowitz, Grace. "Wage Determination in a Labour Surplus Economy: The Case Study of India". Economic Development and Cultural Change. July 1974.

10. Irfan, M. "Effect of Unionization, Product Market Concentration and Foreign Trade on Inter-Industry Wage Structure". Pakistan Development Review. Spring 1981.

11. Irfan, M. "Wages, Employment and Trade Unions in Pakistan". Pakistan Development Review. Spring 1982.

12. Johnston, J. Econometric Methods, MacGraw-Hill, Kogakusha, Ltd., Tokyo. 1972.

13. Kemal, A. R. "An Analysis of Industrial Efficiency in Pakistan, 1958-60 1969-70". Unpublished Ph.D. Thesis, University of Manchester, 1978.

14. Krueger, Anne O. Trade and Employment in Developing Countries, 3: Synthesis and Conclusions. Chicago and London: The University of Chicago Press. 1983.

15. Kuh, Edwin. "A Productivity Theory of Wage Levels - An Alternative to the Phillips Curve". In Norman F. Keiser (ed.), Readings in Macroeconomics: Theory Evidence and Policy. Englewood Cliffs, N.J.: Prentice-Hall. 1970.

16. Leibenstein, Harvey. Economic Backwardness and Economic Growth. New York/London: John Wiley \& Sons. 1960. (Chap. 6)

17. Lewis, W.A. Theory of Economic Growth. Homewood, Ill.: Richard D. Irwin, Inc. 1955.

18. Maslow, H. Abrahm. Motivation to Personality. New York: Harper. 1954.

19. Naqvi, Syed Nawab Haider. "Protection and Economic Development". Kyklos. Vol. XXII - Fasc.1. 1969.

20. Pakistan. Central Statistical Office. Statistical Bulletin. Karachi. (Various issues)

21. Pakistan. Statistical Division. Foreign Trade Statistics of Pakistan. Karachi. (Various issues)

22. Pakistan. Finance Division. Economic Adviser's Wing. Pakistan Economic Survey 1981-82. Islamabad. June 1982.

23. Punjab Bureau of Statistics. Census of Manufacturing Industries. Lahore. (Issues for $1964-65$ to 1977.78 )

24. Webb, Richard. "Wage Policy and Income Distribution in Developing countries" Princeton, N.J.: Princeton University. 1975. (Mimeographed; prepared for the Princeton University-Brookings Institution project on Income Distribution in Less Developed Countries) 